synoptic insight, a reverent and exhilarating certainty of the essential unity of all phenomena appreciable by the mind, and of the omnipresence of an inner reality pervading all, which inspires and pervades the whole life and character of him who experiences it. It is this that equates the amoba with him who has thought his apprehension like a god's; it is this which has created, out of truth and beauty, the atomic bomb which awaits man's dedication of it, in action and not merely in a form of words, to the service of the good; it is the germ of this which Prof. Mottram offers to those who read his book.

For this reason, if for no other, this book can be commended to all those who are seeking at this moment-and desperately seeking-some reintegration of that belief in the existence and even in the good purpose of an inner reality which the recent War, and the evil of those who instigated it, may seem to have shattered beyond recovery. It shows beautifully the moral worth of the service of the truth. Read sincerely and with imagination, it spans the ages of man's experience. With the terrible charity which modern truth must exercise, it links the modern microscope with "the eye of my soul" which beheld, "above my mind, the Light Unchangeable".

G. Lapage.

\section{A GREAT PHYSIOLOGIST}

\section{Léon Fredericg et les débuts de la physiologie en Belgique}

Par Prof. Marcel Florkin. (Collection Nationale, Troisième Série, No. 36.) Pp. 104. (Bruxelles: J. Lebègue et Cie., 1943.) n.p.

$\mathrm{P}$ HYSIOLOGISTS the world over, and especially in Belgium, have reason to be proud of Léon Fredericq. Born in 1851, he became an outstanding figure in the classical period of physiology. Between 1870 and 1880 , the institutes of physiology for the promotion of teaching and the encouragement of research, which came into being in various countries, necessitated the creation of whole-time chairs of physiology. In Belgium such innovations were encouraged by the State, and Léon Fredericq was appointed to the chair at Liège in 1879 in succession to Théodore Schwann, and charged with the creation of a new Institute of Physiology, which was completed in 1888. In the forty-two years during which he directed the Institute, it made history, and on reading this elegant little essay, one realizes why so high a place in world physiology is held by so small a country.

Fredericq's knowledgo was encyclopædic, his experience wide and his talents manifold. Among the latter was high ability as a popular lecturer and as a water colourist. A great naturalist, we owe much to his researches in the comparative field, his most memorable discovery being that of hæmocyanin.

His contacts were closest with France and Germany, and though he had many friends in Britain too, his work was less well known here than it should have been. It is not generally known, for example, that he invented an apparatus, the oxygénographe, applicable for use on man, for reading off oxygen utilization, and recognized by Benedict as a prototype of the arrangement which he so extensively used. He was the initiator of the technique of crossed circulation, and his work on the respiratory exchange as revealed by tonometric determinations, on the left auricular pulsations as studied by œesophageal sounds, and of the time relations of events in the cardiac cycle, is widely known. Much of his work was biochemical and included investigations on blood coagulation : in the course of these he recognized the three main proteins of the plasma.

The book is full of interest, and is a valuable contribution to the history of physiology, with thoroughly painstaking bibliography and footnotes. C. Lovatt Evans.

\section{ACCOUNTING FOR FARMERS}

\section{Good Farm Accounting}

By A. C. Campbell. (Teach Yourself Farming Series.) Pp. 200. (Bickley: English Universities Press, Ltd., 1945.) 3s. 6d. net.

T there is one branch of farming that can be learnt from books it must certainly be book-keoping. Formerly farmers were inclined to regard accounts as an unnecessary encumbrance in a life mostly spent in field and market; but recent changes in taxation have compelled practically all of them to provide statements of their affairs that will satisfy the Inland Revenue authorities.

If we must have accounts, however, let us have them in such a form as to give the maximum amount of information about the running of the business with the minimum of effort.

The author, who has had an extensive and varied farming experience, assumes no previous knowledge of bookkeoping on the part of his readers. Starting from first principles, he leads on through a series of farm accounts posted by double entry, the examples increasing in scope as the more intricate points are illustrated. Thus the treatment of the farmer's personal expenses, produce consumed in the farmhouse and payments in kind to farm workers, are discussed at some length. The interpretation of balance sheet and profit and loss account as a guide to management also receives attention.

For those who desire to keep their accounts in the simplest form consistent with accuracy and efficiency, the author proceeds to describe the singleentry system using an account book of his own design as an illustration.

A section on cost accounting follows. The author shows how cost accounts give a clearer view of the situation in the various farm departments than the purely financial treatment can provide. Further, when handled in mass by experts, they can form a basis for moulding agricultural policy. The nature of the records necessary to build up these accounts is explained with illustrations of the appropriate forms, but it is admitted that the procedure is too exacting for most farmers whose business is not big enough to justify the employment of a clerk.

Information relating to business methods and procedure forms an important part of the book. Certain tables of weights and measures, and valuers scales of compensation are given, some of which might with advantage have been included in an appendix.

The financial accounts are presented in sufficient detail to be readily followed by a beginner. 